\title{
Media Discourse Syntax
}

\author{
Alexandra lorgulescu \\ University of Craiova, A. I. Cuza, no. 13, Craiova, Romania \\ E-mail address: a86iorgulescu@yahoo.com
}

\begin{abstract}
In this article we have emphasized the role of media discourse syntax, so necessary to avoid any misinterpretation. Therefore, understanding the message conveyed by journalists is and will be influenced by word order, sentence type, but also by providing logical links between concepts and ideas play in their own way original. It was found that a contemporary media discourse seeking new concepts to describe functions, meanings and uses of concepts in a particular field, which gradually integrate with older visions through a generality extending existing concepts.
\end{abstract}

Keywords: media; media analysis; message; media discourse syntax

\section{INTRODUCTION}

Speech represents the means through which we select and organize our experiences and the manner in which we learn how to behave, how to react, what to believe and on which we can exert individual control. It is provided to us by a system of rules and signs established from a social - historical point of view, with supra-individual character. The very moment we begin to use language, we enter the labyrinth of social relations. The language represents a mental communication activity through the language, which assigns the common unit in using writing or word by all human beings (Marcu, 2008; Shopovski, 2011; Borowski, 2013a; Borowski, 2013b).

As time passes, we own the language better and better and we identify certain systems of language seeking to characterize ourselves in their terms. We can most often communicate quite efficiently using the resources of a language without necessarily having the direct experience of the activities associated to it.

Verbal communication constitutes an object of exercise, study and perfection, combining the psychological resources, linguistic codes and argumentation structures. The verbal exposure belongs to the oratorical register or to the specialized register of the language. In the exchange of lines, which constitutes the verbal communication, one may transmit information that the sender wants to bring to the receiver's knowledge. The media uses verbal communication very often to transmit information to the target public, under the form of discourse.

Lately, the term "discourse" took more and more different uses and also different acceptations: conversation, dialogue, appointment, an exercise before certain people, allocution, conference, detailed statement, proclamation, speech, apologia, elegy, eulogy, indictment, treaty, any noticeable linguistic statement. As a consequence, all synonyms of the discourse define an essential feature: verbal emission addressed to a person or to a concrete 
crowd. This very thing gives the right to some theoreticians to consider every discourse as argumentative, as it is capable to modify the opinion, spirit, values of the interlocutor. Having a sender and a receiver, plus a concrete and legible message, based on a non-metaphorical code, J. M Adam states that "the discourse is an event, because it is produced by a certain subject, in a certain place and in a certain moment, addressing to a precise addressee" (Preda 2006:61).

In other studies of specialty the discourse is defined as a term "referring more to the vast problematic of a research field than to a certain manner to understand language. The fact that the term assumes the relation of language with the parameters of the non-linguistic reality makes "discourse" be an inter-disciplinary field of research. In this case, the term "discourse" has no plural form, it assigns a generic field" (Bortun, Săvulescu 2005:9) (see also Ogonowska, 2005; Marcu 2011; Shopovski, 2013).

Other interpretations of the discourse aim its equivalence to:

- A text, in which the communicational perspective and the thematic perspective generally coincide (for example, in the case of written communication);

- An assemble of texts, which illustrate the interaction between two or more discourses centred on one theme; in case of conversation, each discourse consists in several texts (each line is a communicational unit, so a text in itself).

As a consequence, each of us are caught in a discursive action: we narrate, we describe, we portray, we teach others, we send letters, we accuse, we ask our rights, we express political opinions, etc. Newspaper reporters must be professionals of discourse, but also of their audience.

Discourse, in fact, consists of the way in which the word circulation is organized in a social communication, producing sense. As a consequence, the information is a problem of discourse. The discourse represents a term which is very analyzed by the researchers and a controversial means of communication, because "discourse exceeds the disciplinary field of linguistics as it does not limit to the analysis of the sentence. Different notions and concepts can be connected to the analysis of the sentence: communication, language functions, psychological and social subject, dialogism, (co)enunciation, acts of language, cohesion and coherence, language-action-interaction, status, role, discursive competences and strategies, conversation, rhetorical operators, argumentative operators, referencing, etc." (RovenţaFrumuşani 2004:4). According to the same author the term discourse knows a multitude of complementary and even contradictory acceptations:

- discourse vs. phrase. Discourse represents a succession of sentences;

- discourse vs. statement. Discourse represents a unit of communication belonging to a specialized discursive gender (novel, newspaper article, touristic brochure).

- discourse vs. language. Language, seen as a system belonging to the members of a community, is opposed to discourse as an individual accomplishment. (idem: 64).

These very complementary but also contradictory acceptations have determined the researchers to reach a common point stating that the analysis of the discourse involves the perspectives of several disciplines. As stated by Maingueneau the analysis of the discourse is regarded as a "...discipline, which instead of proceeding to a linguistic analysis of the text or to a sociological or psychological analysis of its «context», it aims at the articulation of its enunciation (of the text n.n.) at a certain social place, it tries to solve the problem of discursive genders, whether it refers to their belonging to certain discursive fields (political, scientific, etc.) or to the functional relation in the social space (institutions, organizations, etc.)" (D. Maingueneau 1996:11, apud Preda 2006). 
Ch. Morris, in 1938, identified three ${ }^{1}$ fields in the advanced study of every language, either formal or natural:

- syntax, discipline concerning the relation of signs with other signs;

- semantics, discipline referring to relations of signs with reality;

- pragmatics, discipline that takes interest in relations of signs with their users, their use and the effects they produce.

These disciplines set the basis of the scientific premises to which it is called upon in content analysis of publicity messages.

\section{THE DISCOURSE OF MEDIA: ELEMENTS AND SYNTAX}

The media discourse is a generous linguistic-pragmatic field for researchers, because the sender (the journalist) is preoccupied, mainly, with the stake he pursues through his message and less with the form which materializes his information. This is why the media discourses will be, most of the times, textual constructions in which the subject and the object are interdependent. Here is an example in this regard: "I am not afraid to say, but, on top of everything, the Romanian economy “ (Realitatea tv, interview with Daniel Dăianu). In these cases syntax is interested in the relations between the signs which make the publicity message, but it is not responsible for the significance of the symbols configuring the message (Vlăduțescu, 2002; Tenescu, 2007; Marcu \& Iorgulescu, 2009; Ionescu, 2013).

As a matter of fact, it was ascertained that a contemporary discourse seeks new concepts to assign functions, valences and uses of some notions in a certain field, which are, step by step, organically integrated in old visions, by broadening the generalities of the already existing concepts. As a consequence, if these concepts, general in appearance, impoverish or essentialise language, as they absorb nuances in themselves, in reality they make it more elastic, more functional. Examples:

In the following period one announces a major tax, duty and unemployment increase. These measures will make the citizens' situation harder as they generate panic and disillusion. How will Romanians bear this kind of decisions? (Libertatea, November $10^{\text {th }}, 2011$, Mediafax).

In this text the informational part is supported by the affective one, which becomes an argument for it. From the point of view of syntax, direct as well as indirect interrogative constructions are present (the presence of adverbs of manner, which model the discourse).

This way, the brand owner can ask to forbid third parties, especially to apply a sign on products or on packages, product offering, their commercialisation and their possession in this purpose. (Libertatea, no. 7476, March $3^{\text {rd }}, 2013$ ).

In this sentence, the direct object subordinates prevail (in proportion to juxtaposition), which support the informational component.

In this case, the sentences consist of main sentences in report with juxtaposition or coordination, the attributive and the direct object subordinates being preferred (Strechie, 2009; Dima \& Vlăduțescu, 2012b).

Concerning the media functions, more researchers made different classification. For example, Malcolm Wiley made the distinction between five such functions: to supply information, to analyse these information, to give a general reference frame for knowledge, to entertain, to broadcast an encyclopaedic knowledge. Yet, the most important function is the informative one. 
It is said that he who controls the information controls the worlds. But for information to be media valid ${ }^{2}$, it must be a part of a world interpretation system: to describe, to narrate, to explain. The own values (new, actual, verifiable and interesting) are necessary, but not enough. Regardless of the practiced selection, the informational discourse sends knowledge about the world, from three different angles:

Factual. Informational enunciation presented in a discursive form which indicates time, location, period, placed in the utility pages of publications (newspapers).

Eventful. Focalization of the attention on a certain statement (official discourse, press conference) on certain limit situations (accidents, disasters, unforeseen natural phenomena), but also on the persons involved.

Explanatory. One presents the reasons, the intentions, the consequences and the finality of events. The information must not be minimised only to the state of news and it is indicated to be as legible as possible for the reader. The description must answer the questions: Why? How?

Counting on the criteria of efficiency and profitability, the system for producing the information, such as an industrial process, tends to rationalize the current location, selection and treatment methods of infinite and fluctuating eventful raw material. Location not only in the sense of an expectation of the distributed or announced information, which is nothing more than a part of social reality, but also a fruit of the investigation, active curiosity of the journalist. Selection not only through the intrinsic qualities of the events, but also considering the purposes, the resources and the organization structure of the press companies. The treatment and presentations (the package) of the raw material are nothing more than an extension of the initial selection.

Discourse represents a linguistic unit consisting of a succession of phrases, for this reason the syntax exerts a major role in conceiving and defining them (Vlăduțescu, 2006; Bușu, 2013; Traistaru, 2013).

In accomplishing the syntax of own discourses, the journalists must consider the laws of discourse concerning language. "The laws of discourse represent rules that are variable from a cultural point of view, which each partner respects and, at the same time, are to be respected by the interlocutor in the verbal exchange". (Borţun, Săvulescu 2005:46). The fact that they were named "laws", represented the object of ample debates. Some researchers ${ }^{3}$ suggested the theoretical distinction between general discursive principles and specific laws of discourse. This way, in general principles one may include the principle of cooperation, of relevance and sincerity. The classification of laws specific to discourse underlines two important criteria: the linguistic criterion and the criterion focused on behaviour codes.

According to the linguistic criteria, important for us, the following laws exist:

- Informativity Law (protection of the information that is already known);

- Exhaustivity Law (maximum volume of pertinent information);

- Modality Law (transparency and concision ${ }^{4}$ in formulation).

In case a journalist chooses the discourse as a way to send information then syntax of the discourse must be established in such a manner that the main sentences ${ }^{5}$ are situated in the first paragraph. The sender can use diversity when formulating an entire text. "The Code of Language ${ }^{6}$ is not elaborated only in a language considered homogeneous, but it has a dynamic report with other languages (either alive or dead) or with the diversity of one and the same language (dialects, levels of language, specialized discourse etc.)" (idem: 27).

The most frequent classification of discourses approached by the journalists in their work, divides the discourse in written discourse and oral discourse. In journalistic texts the written 
discourse is introduced by means of a postpostioned or prepositioned dicendi verb or by means of a noun and it is graphically signalled by quotation marks, and more rarely, by dialogue line unlike the oral discourse where the reproduced words are integrated in the quoted discourse by transferring them from the discourse plan ${ }^{7}$ to the historical enunciation plan $^{8}$. Here is an example in this respect:

The senators belonging to the leading party threaten their governing colleagues that their projects will end up being rejected, if they do not are not willing to come and support them in commissions and plenum.

Practically, the senators accuse the members of the Government of "defying the Parliament" and the revolt broke out at the Budget-finances Commission. Therefore, the head of this Commission, the social-democrat Cosmin Nicula, informed the president of the Senate, Crin Antonescu, whom he asked to inform the prime minister Victor Ponta, as well, that this type of "insults" will cause the rejection of the law projects sent by the Legislative: "We kindly ask to inform our colleagues, members of the Government, that the ministers should appear for reporting and the state secretaries for resolutions. Thus, the resolutions shall be negative." Taking into consideration that one deals with "institutional relations", Crin Antonescu decided to inform the Government that, in case of an "appropriate non-attendance" at the debate for the law projects in Senate, they shall be rejected, due to "contempt of the Parliament" by the initiators. (S.B.) (Naţional, No. 4831, March $25^{\text {th }}, 2013$ )

Other specialists state that "oral discourse is characterized by means of temporal linearity, unlike the written one, characterized by spatial linearity. Here we get the possibility that members of a paradigmatic series coexist in succession (produce their juxtapositions on syntagmatic axis) or that between certain syntactic constructions contamination takes place" (Ionescu-Ruxăndoiu 1999:11). She also states that "one must not neglect the fact that, in case of oral discourse, a large part of the verbal activity does not serve to transmit referential senses (therefore, of certain information), but only to signal the existence of a recommendation relation that the journalists use the written discourse in sending information to the target public, and the oral discourse could be considered a means to support the relations either with target public or with the subjects of the articles. They refer to the fact that "oral structures are more likely based on addition than subordination, because the determination of the sense is not dependent on grammar exclusively, as it happens in case of writing, but on the assemble of data in the communication situation" (ibidem). So we can talk about the syntax of the media discourse but only in the case of written discourse, where the sender carefully respects the grammar rules because they risk the wrongful perception of the transmitted information (Dima \& Vlăduțescu, 2012a; Vlăduțescu, 2013a; Vlăduțescu, 2013b).

Pragmatics is also specific to a certain conception of language, and more generally, on communication, which is opposed to the structuralist one. She assigns the discipline or the disciplines, which deal with the study of pragmatic element ${ }^{9}$ of the language.

In case of oral discourse at least two interlocutors are needed, while in the written discourse, the receiver is imaginary, and because of this, the sender must be more careful at the used syntax and at the manner of expressing ideas. As stated by Edmondson "if the structure and the evolution of the oral discourse is based on the exploitation of situational resources, the written discourse suggest imagining a receiver and gifting him with a certain type of communicative competence, each assertion representing an answer to an implicit question of the presumptive receiver" (apud Ionescu-Ruxăndoiu 1999:10). 
Also, it is very important that the journalist presents the event (Kulczycki, 2012). The form in which he chooses to present it will directly affect him, because this is the variant visualized by the target public. There are cases in which they do not perceive the event directly, but through the eyes of the journalist and as the journalist must prove objectivity, the form in which he chooses to present the event is very important. So choosing a written discourse as a means to transmit information needs the topic of sentences and syntax to be built in such a manner that the intended information is transmitted (Vlăduțescu \& Ciupercă, 2013). It is true that the form under which the information is transmitted, also depends on the impact it has on society. "This dimension contains the concept of access to media and to the communication channels. This access is usually allowed to subjects of first importance for the society, but the effective selection will be made by a communication medium and by the person controlling it". (Rovenţa-Frumuşani 1999:42). The subjects containing the lowest value, which would be situated at the base of a value scale, are the articles about the statements of certain people (articles of "word story" type). They are followed by articles about what it is said to happen (articles about threats and incentive to act) and about what it is said to be happening or to have already happened (articles about journalistic investigations, about people who transmit what they have discovered). The articles on what happened (articles about events, facts, accidents, disasters, processes, etc.) are situated at the top. As we have already mentioned, an important element in hierarchizing a piece of news is the number of readers which will be absorbed by a certain subject. The larger the impact, the more important the article presenting it will be. The more prolonged the effect of the related events is, the more valuable and more important is the

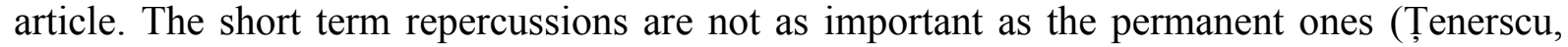
2009; Țenescu, 2010; Vlăduțescu, 2014a; Vlăduțescu, 2014b).

But regardless of the way of transmitting the message and its importance, each must consider the following aspects: choose the adequate terms, build the phrases correctly, write correctly from a grammatical point of view, have an agreeable and captivating style. It is recommended to use words that are full of information and emotional charge, which amplify the resonance.

Essential for efficient communication is the choice of vocabulary ${ }^{10}$, but also the rigor. Seeking the "adequate" word is essential so that the style respects the qualities: precision, clarity, concision, originality and movement. The terms must be adapted to the reality they want to express.

It is necessary to respect the syntax, in order to avoid any error of interpretation. From this perspective, the understanding of the message which must be transmitted is influenced by the type of sentence, the word order, as well as by assuring logical connections between concepts and ideas. Sentences can be simple, composed or complex, but referring to the term order, the syntactic rules usually impose the position of the words.

Concision remains a performance that is difficult to achieve, because it presupposes the existence of short sentences, which express a single idea, avoiding periphrasis, originality, clarity and sobriety. To personalize the presentation, the oratorical talent must be practiced, with accent on nuances, voice inflexions, expressions that are adequate to the event exposed, all with the purpose of convincing and impressing the public. In case of oral discourse, for successful communication and perception, one must not neglect physiology and corporal attitude.

If all these conditions are accomplished, the journalist sends a media information in a correct manner with no other perceptions of communication or a different message. And this happens because syntax and culture assure our continuity, more exactly the cultural matrix guaranteed by syntax is a determinant criteria. 
It has been written quite a lot about the ways in which media discourse should be conceived, but I chose to consult and to mention only those points of view which I identified myself with and support, because to perceive the language of the discourse "means to understand the world generating it, and to understand the world we must go beyond the linguistic frames" (Schiffrin 1994: 419).

\section{CONCLUSION}

The style approached by each journalist, which makes ideas viable, does not only represent the gift of expressing thoughts, but also the art to bring them to the present, to life, to see the connections between them, to confer visibility to them. To acquire such capacity means to have a precise vocabulary, adapted to the situation of communication, therefore, without repetitions, but also with correctly built sentences, which are not too long, respecting the syntactic rules. But style is not reduced to eliminating grammar mistakes or errors concerning language; it may well be said that it suggests a certain originality, an own manner of interpretation. The Specialist in Communication and Public Relations can have a successful discourse by completing the initial verbal communication effect with a different type of procedures aiming at gestures, tonality, rhythm of presentation, respecting the time limit for the discourse.

\section{References}

[1] Borţun D., Săvulescu S. (2005). Analiza discursului public. București: Comunicare.ro

[2] Bălănescu O. (2003). Tehnici discursive publicistice şi publicitate. București: Ariadna'98.

[3] Borowski Andrzej (a). International Letters of Social and Humanistic Sciences 6 (2013) 68-74.

[4] Borowski Andrzej (b). International Letters of Social and Humanistic Sciences 7 (2013) 113-118.

[5] Buşu O. V., European Journal of Business and Social Sciences 2(6) (2013).

[6] Dima I. C., Vlăduțescu Ștefan (2012a). Persuasion elements used in logistical negotiation: Persuasive logistical negotiation. Saarbrucken: LAP Lambert Academic Publishing.

[7] Dima Ioan Constantin, Vlăduțescu Ștefan (b), European Journal of Business and Social Sciences 1(6) (2012) 27-33.

[8] Ionescu-Ruxăndoiu L. (1999). Conversaţia: Structuri şi Strategii. București: All.

[9] Alexandra Iorgulescu, Analele Universității din Craiova, 42.

[10] Alexandra Iorgulescu, Mihaela Marcu, Analele Universității din Craiova, 91 (2009).

[11] Kulczycki,E. (2012). Komunikologia. Teoria i praktyka Komunikacji. Poznan: IF UAM.

[12] Marcu M., Analele Universităţii din Craiova. Seria Ştiinţe Filologice. Lingvistică (1-2) (2008) 82-90.

[13] Marcu M., Analele Universităţii din Craiova. Seria Ştiinţe Filologice. Lingvistică (1-2) (2011) 193-198. 
[14] Marcu M., Iorgulescu A., Analele Universităţii din Craiova. Seria Ştiinţe Filologice. Lingvistică (1-2) (2009) 334-340.

[15] Marcu M., Mihaela Marcu, Analele Universității din Craiova, 145.

[16] Ogonowska A., Nowa Polszczyzna 4(44) (2005) 33-37.

[17] Preda S. (2006). Tehnici de redactare în presa scrisă. Iași: Editura Polirom.

[18] Roventa-Frumuşani D. (1999). Semiotica, societate, cultura. Iaşi: Institutul European.

[19] Roventa-Frumuşani D. (2004). Analiza discursului (ipoteze si ipostaze). București: Editura Tritonic.

[20] Roventa-Frumusani, D. (2012). Discourse hypostases. Hypostases discursives. București: Editura Universității.

[21] Schiffrin D. (1994). Approaches to Discourse. Oxford: Blackwell Publishers.

[22] Shopovski J. (2011). Contribution in the Company. European Scientific Journal, 98.

[23] Shopovski J., Bezzina F., Zammit M. M., The Disqualification of Company Directors and its Effect on Entrepreneurship. European Scientific Journal 9(7) (2013).

[24] Țenescu Alina (2009). Comunicare, sens, discurs. Craiova: Editura Universitaria.

[25] Vlăduţescu Ştefan (2002). Informaţia de la teorie către ştiinţă. Propedeutică la o ştiinţă a informaţiei. Bucureşti: Editura Didactică şi Pedagogică.

[26] Vlăduțescu Ștefan (2006). Comunicare jurnalistică negativă. București: Editura Academiei.

[27] Vlăduțescu Ștefan (a), Jokull Journal 63(8) (2013) 186-197.

[28] Vlăduțescu Ștefan (b), Jokull Journal 3(9) (2013) 301-318.

[29] Vlăduțescu Ștefan (c), Communication Beings: Four Communication Prototypical Figures. International Journal of Education and Research 1(11) (2013).

[29] Vlăduțescu Ștefan, Ciupercă Ella Magdalena (2013). Next Flood Level of Communication: Social Networks. Aachen: Shaker Verlag. 